\title{
Toxoplasma antibody and stool parasites in public school children, Rolândia, Paraná, Brazil
}

\author{
Avaliação da toxoplasmose e enteroparasitas em \\ escolares de Rolândia, PR \\ Nilson Giraldi', Odilon Vidotto², Italmar Teodorico Navarro², \\ João Luis Garcia ${ }^{3}$, Liza Ogawa ${ }^{3}$ and Edmundo Kobylka ${ }^{4}$
}

\begin{abstract}
The occurrence of toxoplasmosis and enteroparasitosis was studied in 434 children from elementary schools in the rural and urban areas of Rolândia, Paraná State, Brazil. Sera and fecal samples from all the students were submitted to IFA for Toxoplasma gondii and coproparasitological tests, respectively. The children were tested by Amsler grid and 72 of them were examined for the presence of lesions compatible with ocular toxoplasmosis. Some variables were tested but none showed increased risk for toxoplasmosis. The distribution according to sex and age and also same other variables are presented and discussed. Correlations between Amsler's grid test, toxoplama RIFl, occurrence of eyes lesions and enteroparasitosis are also considered.

Key-words: Epidemiology. Toxoplasma gondii. School children. Amsler chart. Enteroparasitosis.
\end{abstract}

Resumo Realizou-se exames de imunofluoresência indireta para detecção de anticorpos IgG anti-Toxoplasma gondii e testes com a tela de Amsler em 434 alunos da primeira à quarta série de escolas da rede municipal de Rolândia, PR. Destes, 72 foram examinados para detecção de lesões sugestivas de toxoplasmose em fundo de olho. Estes mesmos alunos e outras 191 crianças de creches tiveram amostras de fezes examinadas para determinar a prevalência de enteroparasitas. A distribuição dos achados, segundo sexo e faixa etária, bem como variáveis que podem influenciar na infeccão por toxoplasma e enteroparasitoses são apresentados $e$ discutidos. Correlações entre resultados da aplicação do teste com a tela de Amsler, sorologia positiva para toxoplasmose, lesões de fundo de olho e ocorrência de enteroparasitas são analisadas.

Palavras-chaves: Epidemiologia. Toxoplasma gondii. Escolares. Tela de Amsler. Enteroparasitoses.

Toxoplasma gondii (Nicole \& Manceaux, 1909), Apicomplexa, an obligatory intracellular protozoan, is the agent of human and animal toxoplasmosis and is distributed world-wide. The prevalence of $T$. gondii may vary from region to region, in accordance with social, cultural and climatic factors ${ }^{15}$.

Felines, the definitive hosts, eliminate oocysts in their feces that contaminate the environment ${ }^{8}{ }^{17}$. In soil, oocysts pass through a sporulation process thus becoming infectious to human and animals ${ }^{14}$.

Human beings may acquire $T$. gondii infections typically through water ingestion and contaminated food, or by direct contact with soil containing sporulated oocysts, as well as ingestion of raw or partially cooked meat containing tissue cysts ${ }^{1823}$.

Toxoplasmic infections in Man are usually asymptomatic, however serious symptoms or even death may occur in the congenital form or in immunocompromised individuals. In its congenital form, the parasite infects the mother and then the fetus which may develop fatal lesions. The child may have a normal delivery, but later present the effects of infection ${ }^{5}{ }^{16}$.

Within the above mentioned possibilities for transmission, ocular toxoplasmosis may have a congenital or acquired origin. Studies performed in southern Brazil have revealed a high frequency of occurrence of

\footnotetext{
1. Curso de Medicina Veterinária da Universidade Norte do Paraná, Arapongas PR. 2. Departamento de Medicina Veterinária Preventiva do Centro de Ciências Agrárias da Universidade Estadual de Londrina, Londrina PR. 3. Departamento de Medicina Veterinária Preventiva e Saúde Animal da Faculdade de Medicina Veterinária e Zootecnia da Universidade de São Paulo, São Paulo, SP. 4. Clínica de Olhos Santa Paula, Rolândia, PR.

Address to: Prof. Nilson Giraldi. PR 218, km 1, 86702-270 Arapongas, PR, Brazil.

Telefax: 5543 274-7700.

E-mail: ngiraldi@yahoo.com.br

Recebido em 14/9/2000.
} 
fundoscopic lesions from acquired toxoplasmosis ${ }^{11}$. Silveira ${ }^{19}$, studying a rural area of Erechim, Rio Grande do Sul, observed that $17.7 \%$ of studied patients showed fundoscopic lesions of toxoplasmic origin.
The main purpose of this work was to study the prevalence of $T$. gondii, and associated factors linked to T. gondii infection, including intestinal parasite, as well as to evaluate visual and ocular alterations in elementary school children in Rolândia, State of Paraná, Brazil.

\section{MATERIAL AND METHODS}

Elementary schools in Rolandia, PR, are attended by 2589 students, 2300 from urban areas and 289 from the rural region. Serologic tests for $T$. gondii, coproparasitologic tests and Amsler chart ${ }^{2}$ were applied to a sample of 276 students from urban areas and 158 from rural regions were performed between October and December, 1998. The size of the sample was determined by the Epi-Info 6 software, selecting pupils at random. At this time, the school children and/or their parents answered a questionnaire concerning epidemiological aspects of toxoplasmosis and enteric parasites: such as the practice of washing hands before meals, ingestion of non-pasteurized milk, raw meat or vegetables, whether their home has a garden, contact with dogs and cats, type of water supply and barefoot walking habits.

Serum levels of IgG class antibodies anti- T. gondii were determined in sera by indirect immunofluorescence antibody Test (IFA), according to standard techniques described by Camargo $^{3}$. Commercial human conjugate anti-IgG (Sigma Chemical, FITC) was used, considering a $1: 16$ dilution as a positive reaction. Positive and negative serum controls were included on each plate.

Fecal samples were brought from student's home in appropriate plastic bottles, and labeled. They were immediately sent to a laboratory and stored in a refrigerator until processed, following the procedures of Faust et $a \Gamma^{\top}$ and Hoffman et $a l^{13}$ to identify helminthes and protozoans.

After obtaining the Amsler chart and serological results, four groups of 18 students were selected at random, and submitted to examination for fundoscopic lesions at a specialized clinic in Rolândia, using a Zeiss split lamp 100/16, and binocular ophthalmoscopy ${ }^{19}$. The groups were organized as follows: Group A - Serumpositive, with alterations on Amsler chart; Group B Serum-positive, without alterations on Amsler chart; Group C - Serum-negative, with alterations on Amsler chart and Group D - Serum-negative, without alterations on Amsler chart.

The odds ratio was calculated to establish associations between the variables studied and statistical significance level was determined when the $95 \%$ confidence interval did not include one. The associations between the groups was tested using the Chi-square test with statistical significance considered when $p \leq 0.05$. The correlation coefficient was determined as described by Ulon \& Marder ${ }^{21}$.

\section{RESULTS}

Of 343 serum samples analyzed, $42.4 \%$ were positive for T. gondii. In 276 students from urban schools, 116 (42\%) displayed positive serology. In 158 students from rural schools, 68 (43\%) were positive by IFA. There was no difference in the prevalence rates of $T$. gondiiantibodies between urban and rural students $\left(x^{2}=0.04 p=0.83\right)$.

The distribution of reactive individuals and the results of coproparasitologic tests according to each school are presented in Table 1. Statistical treatment revealed no differences in the prevalence of $T$. gondii antibodies between urban or rural schools. Concerning enteroparasitosis, only urban areas showed significant differences between schools $\left(x^{2}=36.9 p<0.01\right)$. Correlation studies between anti-T.gondii antibodies and the prevalence of enteroparasitosis compared for each school, revealed a positive and significant correlation in urban areas $(r=0.75 p=0.04)$. The same did not occur in rural areas. The most frequent titer was $256(23.3 \%$ in urban areas and $35.4 \%$ in rural areas) (Table 2).

There was no substantial sex bias in either urban or rural areas. In urban areas, $50(44.2 \%)$ of boys and $66(40.5 \%)$ of girls $\left(x^{2}=0.39 p=0.53\right)$ were seropositive. In rural areas $32(43.2 \%)$ of boys and $36(42.9 \%)$ of girls $\left(x^{2}=0.00 p=0.96\right)$ were seropositive.
When children were divided into age groups of 6 to 7,8 to 9 and 10 years old or over, it was shown that of 276, 116 (42\%) were seropositive for T. gondii antibodies in urban schools, $27(36 \%)$ were positive in the 6 to 7 years old group; $50(43.5 \%)$ in the 8 to 9 years old group and $39(45.4 \%)$ in those over 10 years. In rural schools, out of $158,68(43 \%)$ were seropositive, with $8(23.5 \%)$, $32(47.8 \%)$ and $28(49.1 \%)$ in the respective age groups (urban area $x^{2}=1.61 p=0.04$ and rural area $x^{2}=6.75 p$ $=0.03$ ). Therefore, only children from the rural area exhibited a difference in the distribution of $T$. gondii antibody according to age (Table 3).

From the Amsler chart application, of 434 tested students, $151(34.8 \%)$ revealed visual alterations, 120 (79.5\%) from urban areas and $31(20.5 \%)$ from rural schools $\left(O R=3.151 .95<O R>5.12 x^{2}=25.21 p<0.01\right)$.

In the 120 urban students that displayed Amsler chart changes, $56(48.3 \%)$ showed a positive serology for T. gondii and, of the 156 that did not reveal visual changes in chart application, $60(51.7 \%)$ presented positive serology. From 31 rural students who presented Amsler chart alteration $12(17.6 \%)$ were seroreactive and from 127 students without visual alterations, 56 
Table 1 - Distribution of IgG anti-T. gondii antibodies by immunofluorescence test (IFA) and results of coproparasitologic tests, grouped according to origin of elementary students' school, Rolândia, PR, Brazil, 1998.

\begin{tabular}{|c|c|c|c|c|c|c|c|c|c|c|}
\hline \multirow[b]{3}{*}{ School } & \multicolumn{4}{|c|}{ IFA } & \multicolumn{4}{|c|}{ Coproparasite } & \multirow{2}{*}{\multicolumn{2}{|c|}{ total }} \\
\hline & \multicolumn{2}{|c|}{ positive } & \multicolumn{2}{|c|}{ negative } & \multicolumn{2}{|c|}{ positive } & \multicolumn{2}{|c|}{ negative } & & \\
\hline & $\mathrm{N}$ & $\%$ & $\mathrm{~N}$ & $\%$ & $\mathrm{~N}$ & $\%$ & $\mathrm{~N}$ & $\%$ & $\mathrm{~N}$ & $\%$ \\
\hline \multicolumn{11}{|c|}{ Urban area } \\
\hline A & 12 & 37.5 & 20 & 62.5 & 6 & 18.8 & 26 & 81.2 & 32 & 11.6 \\
\hline B & 22 & 39.3 & 34 & 60.7 & 29 & 51.8 & 27 & 48.2 & 56 & 20.3 \\
\hline C & 8 & 57.1 & 6 & 42.9 & 11 & 78.6 & 3 & 21.4 & 14 & 5.0 \\
\hline$D$ & 7 & 35.0 & 13 & 65.0 & 11 & 55.0 & 9 & 45.0 & 20 & 7.3 \\
\hline $\mathrm{E}$ & 7 & 33.3 & 14 & 66.7 & 6 & 28.6 & 15 & 71.4 & 21 & 7.6 \\
\hline $\mathrm{F}$ & 18 & 36.7 & 31 & 63.3 & 28 & 57.1 & 21 & 42.9 & 49 & 17.7 \\
\hline G & 42 & 50.0 & 42 & 50.0 & 61 & 72.6 & 23 & 27.4 & 84 & 30.5 \\
\hline \multirow[t]{2}{*}{ Subtotal } & 116 & 42.0 & 160 & 58.0 & 152 & 55.1 & 124 & 44.9 & 276 & 100.0 \\
\hline & \multicolumn{4}{|c|}{$\left(x^{2}=5.57 p=0.47\right)$} & \multicolumn{4}{|c|}{$\left(x^{2}=36.9 p<0.01\right)$} & \multicolumn{2}{|c|}{$(r=0.75 p=0.04)$} \\
\hline \multicolumn{11}{|c|}{ Rural area } \\
\hline $\mathrm{H}$ & 5 & 33.3 & 10 & 66.7 & 5 & 33.3 & 10 & 66.7 & 15 & 9.5 \\
\hline I & 9 & 32.1 & 19 & 67.9 & 17 & 60.7 & 11 & 39.3 & 28 & 17.7 \\
\hline $\mathrm{J}$ & 18 & 56.3 & 14 & 43.8 & 12 & 37.5 & 20 & 62.5 & 32 & 20.3 \\
\hline $\mathrm{K}$ & 10 & 41.7 & 14 & 58.3 & 14 & 58.3 & 10 & 41.7 & 24 & 15.2 \\
\hline L & 9 & 45.0 & 11 & 55.0 & 7 & 35.0 & 13 & 65.0 & 20 & 12.7 \\
\hline M & 10 & 41.7 & 14 & 58.3 & 12 & 50.0 & 12 & 50.0 & 24 & 15.2 \\
\hline $\mathrm{N}$ & 7 & 46.7 & 8 & 53.3 & 9 & 60.0 & 640.0 & 15 & 9.5 & \\
\hline \multirow[t]{2}{*}{ Subtotal } & 68 & 43.0 & 90 & 57.0 & 76 & 48.1 & 82 & 51.9 & 158 & 100.0 \\
\hline & \multicolumn{4}{|c|}{$\left(x^{2}=4.36 p=0.60\right)$} & \multicolumn{4}{|c|}{$\left(x^{2}=7.80 p=0.25\right)$} & \multicolumn{2}{|c|}{$(r=-0.22 p=0.63)$} \\
\hline Total & 184 & 42.4 & 250 & 57.6 & 228 & 52.5 & 206 & 47.5 & 434 & 100.0 \\
\hline
\end{tabular}

Table 2 - Reciprocal serologic titers anti-T. gondii IgG obtained from IFA, according to urban or rural elementary school children of Rolândia, PR, Brazil, 1998.

\begin{tabular}{|c|c|c|c|c|c|c|}
\hline \multirow[b]{3}{*}{ Titer } & \multicolumn{4}{|c|}{ Reagents } & & \\
\hline & \multicolumn{2}{|c|}{ urban area } & \multicolumn{2}{|c|}{ rural area } & \multicolumn{2}{|c|}{ Total } \\
\hline & $\mathrm{n}$ & $\%$ & $n$ & $\%$ & $n$ & $\%$ \\
\hline$\overline{16}$ & 24 & 20.7 & 10 & 14.7 & 34 & 18.5 \\
\hline 64 & 24 & 20.7 & 12 & 17.6 & 36 & 19.6 \\
\hline 256 & 27 & 23.3 & 24 & 35.4 & 51 & 27.7 \\
\hline 1024 & 23 & 19.8 & 10 & 14.7 & 33 & 17.9 \\
\hline 4096 & 18 & 15.5 & 12 & 17.6 & 30 & 16.3 \\
\hline Total & 116 & & 68 & & 184 & 100.0 \\
\hline
\end{tabular}

(82.4\%) were seropositive (urban area $x^{2}=1.87 \mathrm{p}=$ 0.17 and rural area $x^{2}=0.29 p=058$ ). There was no correlation between results of Amsler chart examination and serology for T. gondii (urban area $p=0.47$ and rural area $p=027$ ) (Table 4$)$. Upon fundoscopy, none of the students revealed any form of lesion.

Coproparasitologic tests showed that, from 434 students, 228 (52.5\%) had enteric parasites, 152 $(55.1 \%)$ from urban and $76(48.1 \%)$ from rural schools $\left(x^{2}=1.96 p=0.16\right)$. There was a higher prevalence of protozoans than of helminthes. Giardia lamblia was present in 149 (34.33\%) students, whereas other
Table 3 - Detection of IgG antibodies anti-T. gondii by IFA grouped by according to pupils in the first to fourth grades in Rolândia public schools PR, Brazil, 1998.

\begin{tabular}{|c|c|c|c|c|c|c|}
\hline \multirow[b]{3}{*}{ Age group } & \multicolumn{4}{|c|}{ IFA } & & \\
\hline & \multicolumn{2}{|c|}{ positive } & \multicolumn{2}{|c|}{ negative } & \multicolumn{2}{|c|}{ Total } \\
\hline & $\mathrm{n}$ & $\%$ & $\mathrm{n}$ & $\%$ & $\mathrm{n}$ & $\%$ \\
\hline \multicolumn{7}{|l|}{ Urban area } \\
\hline 6 a 7 & 27 & 36.0 & 48 & 64.0 & 75 & 27.2 \\
\hline 8 a 9 & 50 & 43.5 & 65 & 56.5 & 115 & 41.7 \\
\hline$\geq 10$ & 39 & 45.4 & 47 & 54.6 & 86 & 31.1 \\
\hline Subtotal & 116 & 42.0 & 160 & 58.0 & 276 & 100.0 \\
\hline \multicolumn{7}{|c|}{$\left(x^{2}=1.61 p=0.44\right)$} \\
\hline
\end{tabular}

\begin{tabular}{|c|c|c|c|c|c|c|}
\hline \multicolumn{7}{|c|}{ Rural area } \\
\hline 6 a 7 & 8 & 23.5 & 26 & 76.5 & 34 & 21.5 \\
\hline 8 a 9 & 32 & 47.8 & 35 & 52.2 & 67 & 42.4 \\
\hline$\geq 10$ & 28 & 49.1 & 29 & 50.9 & 57 & 36.1 \\
\hline Subtotal & 68 & 43.0 & 90 & 57.0 & 158 & 100.0 \\
\hline \multicolumn{7}{|c|}{$\left(x^{2}=6.75 p=0.03\right)$} \\
\hline tal & 184 & 42.4 & 250 & 57.6 & 434 & 100.00 \\
\hline
\end{tabular}

protozoans (Endolimas nana, Entamoeba coli and Entamoeba histolytica) were detected in 111 (25.58\%) students. Nematodes (Ascaris lumbricoides, Ancylostoma $\mathrm{sp}$, Trichuris trichiura and Enterobius vermicularis) were found in 57 (13.13) students. The only cestode found was Hymenolepis nana in 11 (2.53\%) students.

\section{DISCUSSION}

Considering the ages of the individuals studied, we conclude that the prevalence of $42.2 \%$ seropositive titers for $T$. gondii is very high when compared to results from other authors in Southern Brazil, Sudan or Mexico ${ }^{1215}$. 
Table 4 - Association between IgG anti-T. gondii IFA results and findings on application of Amsler chart among elementary school students from Rolândia, PR, Brazil, 1998.

\begin{tabular}{|c|c|c|c|c|c|c|}
\hline \multirow{3}{*}{ I F A } & \multicolumn{4}{|c|}{ Amsler chart } & & \\
\hline & \multicolumn{2}{|c|}{ with alteration } & \multicolumn{2}{|c|}{ no alteration } & \multicolumn{2}{|c|}{ Total } \\
\hline & $\mathrm{n}$ & $\%$ & $\mathrm{n}$ & $\%$ & $\mathrm{n}$ & $\%$ \\
\hline \multicolumn{7}{|c|}{ Urban area } \\
\hline Positive & 56 & 48.3 & 60 & 51.7 & 116 & 42.0 \\
\hline Negative & 64 & 40.0 & 96 & 60.0 & 160 & 58.0 \\
\hline \multirow[t]{2}{*}{ Subtotal } & 120 & 43.5 & 156 & 56.5 & 276 & 100.0 \\
\hline & \multicolumn{4}{|c|}{$\left(x^{2}=1.87 p=0.17\right)$} & \multicolumn{2}{|c|}{$(r=0.32 p=0.47)$} \\
\hline \multicolumn{7}{|c|}{ Rural area } \\
\hline Positive & 12 & 17.6 & 56 & 82.4 & 68 & 43.0 \\
\hline Negative & 19 & 21.1 & 71 & 78.9 & 90 & 56.0 \\
\hline \multirow[t]{2}{*}{ Subtotal } & 31 & 19.6 & 127 & 80.4 & 158 & 100.0 \\
\hline & \multicolumn{4}{|c|}{$\left(x^{2}=0.29 p=0.58\right)$} & \multicolumn{2}{|c|}{$(r=0.47 p=0.27)$} \\
\hline Total & 151 & 34.8 & 283 & 65.2 & 434 & 100.0 \\
\hline
\end{tabular}

Although, Garcia ${ }^{9}$ found similar results (43.8\%) in a neighboring town when evaluating the same age groups.

Students of urban or rural origin did not show significant differences. Authors studying the same region, have described that the toxoplasmic infection risk is greater in rural populations ${ }^{1023}$. However, there was no difference when considering the student's school origin, they exhibited a very similar distribution in urban or rural zones. The majority of antibody titers were less than $1,024(64.7 \%$ in urban zone and $67.7 \%$ in rural), a fact that may characterize previous infections by $T$. gondii, as suggested by Velasco Castrejón et $a^{R^{2}}$. Such similarities suggest common risk and infection sources throughout the city. Being familiar with the demographics of the city, we can affirm that similar risks are present because the urban populations have recent rural origins and similar habits and culture.

The sex of the children did not reveal significant differences by IFA analysis for $T$. gondii, suggesting that both genders have the same contact risk with the agent.

There were differences according to age in antibody prevalence infection, which was directly proportional. The age-related antibody prevalence was similar to other authors $^{920}$. The age results indicate that the infection is postnatal.

Other factors, such as habits of ingesting raw meat or vegetables; contact with dogs or cats or even having pets that frequent gardens; habit of washing hands before meals; origin of drinking water, disposal of feces and walking barefoot did not influence the serological results, in accordance with Garcia's results ${ }^{9}$. Camargo et a/ studying toxoplasmosis in urban areas of Minas Gerais State, observed a higher antibody prevalence in individuals that reported inadequate housing, periodic contact with cats, chickens and pigs. Although, feeding habits, contact with dogs, goats and rodents did not influence the seroprevalence.

There was a significant correlation between seroprevalence for $T$. gondii with presence of enteroparasites in urban areas. The same was not observed in rural areas. Such results suggest that the transmission source for toxoplasmosis and enteroparasitosis were the same, occurring via soil, water and food. This is in agreement with the finding in studies by Etheredge \& Frenkel $^{6}$ that oocyst transmission is most common in Latin America.

The absence of a correlation between enteroparasites and toxoplasmosis in rural areas may be explained and children live in common space ${ }^{22}$, the neighborhood inhabited by them is large, which would contribute to reduce the risk of acquiring $T$. gondii via food contamination due to exposure from their surroundings.

Comparing urban and rural students with visual alterations, we observed a higher risk of these alterations in urban students. The Amsler chart was described as a simple and rapid test for the evaluation of the macular visual field ${ }^{2}$, although recent studies have demonstrated low sensitivity and specificity of the test ${ }^{1}$, which may explain the absence of fundoscopic lesions even in students that presented Amsler chart alterations. There was no correlation between T. gondii serology and Amsler chart findings.

Although the present study did not demonstrate Amsler chart efficacy to detect fundoscopic lesions among school children, Garcia ${ }^{9}$, from a trial using this method, was able to detect 9 patients with lesions suggestive of toxoplasmosis in 41 seropositive patients with chart alterations and all of these were more than 30 years old.

The ages studied showed a low prevalence for ocular toxoplasmosis, as demonstrated by Silveira ${ }^{19}$ in a study of ocular lesions suggestive of toxoplasmosis in rural populations of Erechim, RS, Brazil. In this study, with 1,042 patients of all ages, only one of the children presented fundoscopic lesions.

Further studies to evaluate the efficacy of the Amsler chart in detecting ocular toxoplasmosis need to be performed.

Our work showed a high prevalence of anti- $T$. gondii antibodies, in the early ages studied. The same occured with enteric parasitosis. This suggested that urban populations in the studied areas had similar sanitary characteristics to the rural areas. These children have a potential risk of presenting ocular toxoplasmosis in the future. Hence, the importance for schools to monitor visual acuity cannot be overemphasized. Control measures and especially sanitary education should be provided in schools, which would hopefully reduce such high a prevalence of these infections. 


\section{REFERENCES}

1. Achard AO, Safran AB, Duret FC, Ragama E. Role of the completion phenomenon in the evaluation of Amsler grid results. American Journal of Ophthalmology 120:322-329, 1995.

2. Amsler M. Earliest symptoms of diseases of the macula. British Journal of Ophthalmology 37:521-537, 1953.

3. Camargo ME. Improved technique of indirect immunofluorescence for serological diagnosis of toxoplasmosis. Revista do Instituto de Medicina Tropical de São Paulo 6:117-118, 1964.

4. Camargo MCV, Antunes CMF, Chiari CA. Epidemiologia da infecção por Toxoplasma gondii no município de Ribeirão das Neves, MG. I. Importância do animais domésticos como fonte de infecção do $T$. gondi para o homem. Revista da Sociedade Brasileira de Medicina Tropical 28:211-214, 1995.

5. Dressen DW. Toxoplasma gondii. Journal of America Veterinary Medicine Association 196:274-276, 1990.

6. Etheredge GD, Frenkel JK. Human Toxoplasma infection in Kuna and Embera children in the Bayano and San Blas, eastern Panama. American Journal of Tropical Medicine and Hygiene 53:448-457, 1995.

7. Faust EC, D'Antoni JS, Odrom V, Miller MJ, Peres C, Sawitz W, Thomen LF, Tobie J, Walker JH. A critical study of clinical laboratory techniques for the diagnosis of protozoan, cysts and helminth eggs in feces. American Journal of Tropical Medicine 18:169-183, 1938.

8. Frenkel JK, Dubey JP, Miller NL. Toxoplasma gondii in cats fecal stages identified as coccidian oocysts. Science 167:893-896, 1970.

9. Garcia JL. Epidemiologia do Toxoplasma gondii, na população de animais e humanos, dentro do ecossistema da doença. Tese (mestrado) Universidade Estadual de Londrina, 1998.

10. Garcia JL, Navarro IT. Levantamento soroepidemiológico da toxoplasmose em moradores da zona rural do município de Guaraci Paraná - Brasil. Semina: Ciências Agrárias 16:63-67, 1995.

11. Glasner PD, Silveira $C$, Kruszon-Moran D, Martins CM, Burnier Jr M, Silveira S, Camargo ME, Nussenblatt RB, Kaslow RA, Belfort Jr R. An unusually high prevalence of ocular toxoplasmosis in southern Brazil. America Journal of Ophthalmology 114:136-144, 1992.

12. Goldsmith RS, Kagan IG, Zarate R, Reyes-Gonzales MA, Cedeno-Ferreira J. Low toxoplasma antibody prevalence and serological surveys of human in southern Mexico. Archivos de Investigacion Medica (Mexico) 22:63-73, 1991.
13. Hoffman WA, Pons JA, Janer JL. The sedimentation-concentration method in Schistosomiasis mansoni Puerto Rico. Journal of Public Health 9:283-291, 1934.

14. Lappin MR, Greene CE, Prestwood AK, Dawe DL, Tarleton RL. Enzyme-linked immunosorbent assay for the detection of circulation antigens of Toxoplasma gondii in the serum of cats. American Journal of Veterinary Research 50:1586-1590, 1989.

15. Melamed J, Sebben JC, Maestri M, Silveira S, Locatelli C. Epidemiology of ocular toxoplasmosis in Rio Grande do Sul, Brazil. Brussels, Belgium: Recent Advances in Uveites, Proceeding of Third International Symposium on Uveitis p. 211-214, 1992.

16. McCabe R, Remington JS. Toxoplasmosis; the time has come. The New England Journal of Medicine 318:313-315, 1988.

17. Miller NL, Frenkel JK, Dubey JP. Oral infections with Toxoplasma cysts and oocysts in felines, other mammals and birds. Journal of Parasitology 58:928-937, 1972.

18. Navarro IT, Vidotto $O$, Giraldi N, Freire RL. Estudo da resistência do Toxoplasma gondii ao efeito do cloreto de sódio e condimentos em linguiça frescal de suínos. Boletin Sanitario Panamericano 112:138-143, 1992.

19. Silveira CAM. Estudo da toxoplasmose ocular em Erechim-RS. Tese (doutorado) Escola Paulista de Medicina, Universidade Federal de São Paulo, São Paulo, SP, 1997.

20. Souza WJS, Coutinho SG, Lopes CWG, Santos CS, Neves NM, Cruz AM. Epidemiological aspects of toxoplasmosis in schoolchildren residing in localities with urban or rural characteristics within the city of Rio de Janeiro, Brazil. Memórias do Instituto Oswaldo Cruz 82:475-482, 1987.

21. Ulón SN, Marder G. Tasas de infección toxoplasmica en el hombre y su relacion com los animales domesticos en al ciudad de Corrientes. Veterinaria Argentina 7:518-522, 1990.

22. Velasco-Castrejón O, Salvatierra-Izaba B, Valdespino JL, Sedano-Lara AM, Galindo-Virgem S, Magos C, Llausás A, Tapia-Conyer R, Gutiérrez G, Sepúlveda, J. Seroepidemiología de la toxoplasmosis en México. Salud Publica de México, 34:222-229, 1992.

23. Vidotto O, Navarro IT, Giraldi N, Mitsuka R, Freire RL. Estudos epidemiológicos da toxoplasmose em suínos da região de Londrina - PR. Semina 11:53-59, 1990. 